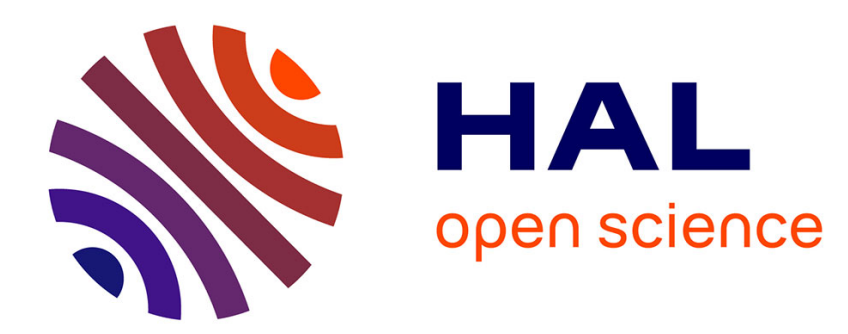

\title{
PULSED LASER PLASMOTRONS
}

\author{
P. Nikitin, S. Uglov, V. Konov
}

\section{To cite this version:}

P. Nikitin, S. Uglov, V. Konov. PULSED LASER PLASMOTRONS. Journal de Physique IV Proceedings, 1991, 01 (C7), pp.C7-142-C7-142. 10.1051/jp4:1991738 . jpa-00250977

\section{HAL Id: jpa-00250977 https://hal.science/jpa-00250977}

Submitted on 1 Jan 1991

HAL is a multi-disciplinary open access archive for the deposit and dissemination of scientific research documents, whether they are published or not. The documents may come from teaching and research institutions in France or abroad, or from public or private research centers.
L'archive ouverte pluridisciplinaire HAL, est destinée au dépôt et à la diffusion de documents scientifiques de niveau recherche, publiés ou non, émanant des établissements d'enseignement et de recherche français ou étrangers, des laboratoires publics ou privés. 


\section{PULSED LASER PLASMOTRONS}

P.I. NIKITIN, S.A. UGLOV and V.I. KONOV

General Physics Institute, USSR Academy of Sciences, 38 Vavilov str., Moscow 117942, USSR

A method of material processing not directly by laser beams but with the help of gas pulsed optical breakdown plasma is investigated. If the gas is chemically active the new approach to material surface treatment can be realized - laser plasma induced synthesis of different compounds.

High repetition rate $\mathrm{TEA} \mathrm{CO}_{2}$-laser with the energy of $2 \mathrm{~J}$ in microsecond pulses and repetition rate up to $300 \mathrm{~Hz}$ was used. The irradiated samples was positioned in chamber with various gases.

Surface nitration of Ti, Zr, Hf transition metals and same types of steel was performed by using of optical breakdown of gaseous $\mathrm{N}_{2}$. Layers of nitrogen containing compounds with enhanced microhadness and thickness up to $40 \mathrm{\mu m}$ were obtained. The influence of laser parameters, sample surface condition, $\mathrm{N}_{2}$ pressure and presence of admixture oxygen on the synthesised compounds composition and properties were studied.

The optical breakdown plasma in the mixture of iron pentacarbonyl vapors and silane with argon was used to obtain iron and silicon thin films. It has been found that parameters of the film (thickness, adhesion, density, composition) depend on partial pressure and the kind of gases (reactant or buffer), as well as on the propagation modes of optical discharge. Films formed in silane-argon mixture consist of hydrogenated silicon Si:H. Hydrogen content in silicon films is as high as 10\%, this being advantageous when using them in thin solar cells.

It is shown that multipulse laser irradiation of some insulator ceramic samples $\left(\mathrm{TiO}_{2}, \mathrm{ZrO}_{2}, \mathrm{HfO}_{2}\right)$ in an, ammonia atmosphere, surface layers are synthesized exhibiting a complicated morphology and having a complex structure containing, beside metallic nitrides, nonstoichiometric oxygen-depleted oxides and oxinitrides. Such layers have a diminished sheet resistance, and display good conduction characteristics.

It is shown that pulsed laser plasmotron chemical action can be highly localized (within the irradiation spot area) and very efficient. 